\title{
A new hierarchy of human motives updates environmental culture thoughts
}

\author{
Quy Van Khuc ${ }^{1,2}$ \\ ${ }^{1}$ Vietnam National University, Hanoi, Vietnam \\ ${ }^{2}$ Vietkaplab, Hanoi, Vietnam \\ December 11, 2021; \\ Preprint DOI: https://osf.io/vx69u \\ Email: qvkhuc.4vina@gmail.com
}

\section{Short notes}

The wealth of mankind has grown rapidly in the last century. According to Our World in Data (DataOurWorldinData, 2017), the world's GDP increased by more than 21 times between 1913 and 2013. Among many theories (models) that can explain this growth, I believe that Maslow's motivation theory (A. H. Maslow, 1943) continues to play an important role in deeply explaining the origins of the human's economic growth, progress and evolution associated with working and innovations.

Maslow's hierarchy of needs broadly refers to a variety of human needs associated with a self-value system that is attributed to from-low-to-high levels. Although the theory has many advantages (applications), for example, organizations often use it to develop appropriate management strategies to maximize productivity (profit), it is flawed because it overlooks environmental culture values (thoughts). The theory, in other words, just mentions personal needs while omitting "for-nature \& humanity" needs (non-personal needs).

Here, I propose a new hierarchy of human motives (advanced Maslow tower) that adds (updates) environmental culture thoughts (tư tưởng hướng thượng/đạo hướng thượng) (Khuc, 2021a, 2021c; Q.-H. Vuong, 2021; Q. H. Vuong, 2021; Q. H. Vuong et al., 2021) as the highest level of the human's motivation ladder (Figure 1). 


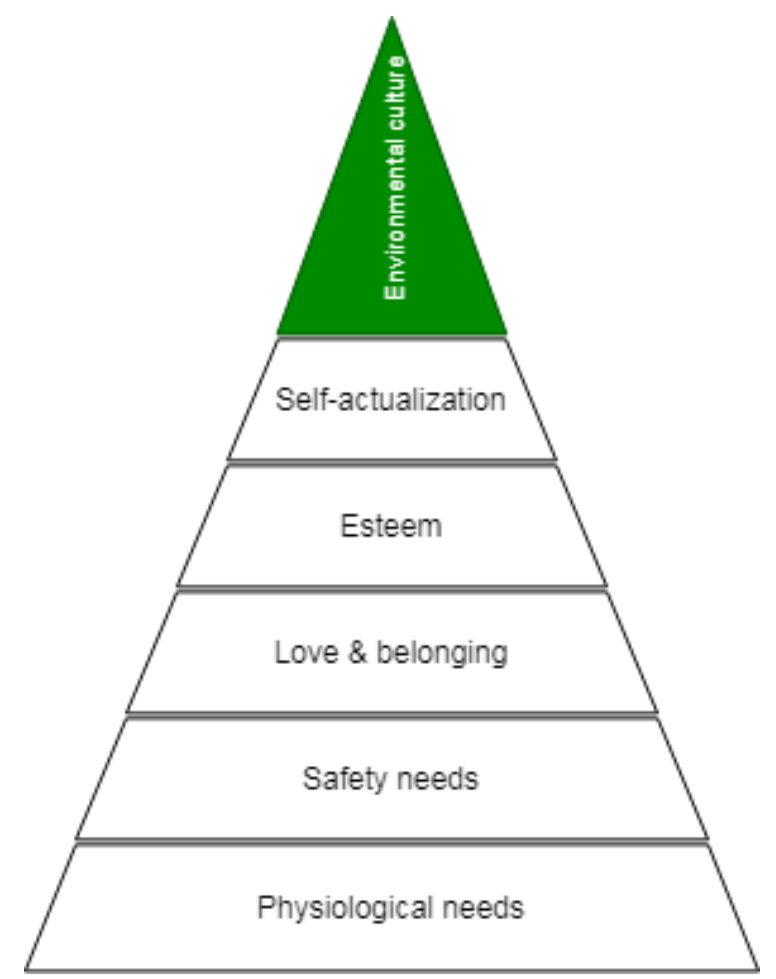

Figure 1. An advanced Maslow tower of human motives

Environmental culture thoughts first is to remind yourself, remember, practice saving resources every day (Khuc, 2021c). Next, environmental culture thoughts are the need for protecting and improving the environment (nature) without any conditions. Very importantly, environmental culture thoughts include advocating and strictly applying environmental protection principles such as semi-conducting principles (Q. H. Vuong, 2021), thiennhienism (Khuc, 2021c) at anytime, anywhere.

While environmental culture thoughts (tư tưởng hướng thượng/đạo hướng thượng) are the highest level of the hierarchy of needs, and it truly reflects the need to contribute to enriching nature (environment) and society instead of the need to satisfy individual needs only. On the one hand, I believe that environmental culture thoughts are the new motive of mankind to tackle environmental issues (climate change) in this century and later on; on the other hand, they are the ultimate goal for people to strive for.

Certaintly, it is extremely difficult, but a normal person may reach environmental culture thoughts. To be specific, one can gradually upgrade their self-value system to the highest level of the human motivation ladder if one has a pure virtue with an unconditional giving heart, are smart enough to ask the right questions (Khuc, 2021b) to do, and strictly practice (apply) the 3DMS system (Napier, N. K., \& Vuong, 2013; Q. H. Vuong \& Napier, 2014, 2015) for a long time enough.

In short, I here introduce the advanced Maslow tower that includes both personal and nonpersonal needs (environmental culture thoughts - tư tưởng thướng thương/đạo hướng thượng). This human motivation theory, in my point of view, would reflect and shape a 
manner (beautiful living culture) associated with a new motivation to make our world better for nature and children.

Acknowledgment: I would like to especially thank Prof. Vuong Quan Hoang for his valuable inspiration and supports thus far.

\section{References}

A. H. Maslow. (1943). A theory of human motivation. Psychological Review, 370-396. https://doi.org/10.1037/h00543463_12

DataOurWorldinData. (2017). Our World in Data. https://ourworldindata.org/grapher/world-gdp-over-the-last-two-millennia.

Khuc, Q. Van. (2021a). Environmental culture thoughts to make a better world for our nature and children. OSF Preprints. https://doi.org/10.31219/osf.io/g5zex

Khuc, Q. Van. (2021b). Questioning in the 3D-Mindsponge-Serendipity (3DMS) system. OSF Preprints. https://doi.org/10.31219/osf.io/uz2yn

Khuc, Q. Van. (2021c). Thiennhienism. OSF Preprints, 2. https://doi.org/10.31219/osf.io/yd4h6

Napier, N. K., \& Vuong, Q. H. (2013). Serendipity as a strategic advantage?. In: Wilkinson (ed.) Strategic Management in the 21st Century (pp. 175-199). Praeger/ABC-Clio.

Vuong, Q.-H. (2021). Western monopoly of climate science is creating an eco-deficit culture. Economy, Land \& Climate Insight, 1-9.

Vuong, Q. H. (2021). The semiconducting principle of monetary and environmental values exchange. Economics and Business Letters, 10(3), 284-290.

https://doi.org/10.17811/ebl.10.3.2021.284-290

Vuong, Q. H., Ho, M. T., Nguyen, M. H., Pham, T. H., Vuong, T. T., Khuc, Q., Ho, H. A., \& La, V. P. (2021). On the environment-destructive probabilistic trends: A perceptual and behavioral study on video game players. Technology in Society, 65(January), 101530. https://doi.org/10.1016/j.techsoc.2021.101530

Vuong, Q. H., \& Napier, N. K. (2014). Making creativity: the value of multiple filters in the innovation process. International Journal of Transitions and Innovation Systems, 3(4), 294. https://doi.org/10.1504/ijtis.2014.068306

Vuong, Q. H., \& Napier, N. K. (2015). Acculturation and global mindsponge: An emerging market perspective. International Journal of Intercultural Relations, 49, 354-367. https://doi.org/10.1016/j.ijintrel.2015.06.003 